\title{
The Political Economy of China-Myanmar Bilateral Relations Under the framework of Belt and Road Initiative
}

\author{
Kyaw Htet Aung \\ Department of Political Science, National Cheng Kung University, Taiwan \\ Corresponding Author: kyawhtetaungame@gmail.com
}

\section{Article Info}

\section{Keyword:}

Myanmar;

China;

Belt and Road

Initiative;

State-Market-Society

Analysis

\author{
Kata Kunci: \\ Myanmar1; \\ China; \\ Belt and Road \\ Initiative; \\ Analisis Negara- \\ Pasar-Masyarakat
}

\begin{abstract}
After the political transition of Myanmar in 2011, China's engagement strategy toward Myanmar has led the changes from the state-to-state relations into the multi-layered relations. At the same time, Myanmar's foreign policy has also challenged Beijing's economic and political interests in Myanmar in terms of the Myit-Sone Dam suspension by Myanmar's first reform government. Later, the Aung San Suu Kyi's government looks more closely with the PRC under the framework of the Belt and Road Initiative. In this sense, it could be interesting to find Myanmar's policy on China's engagement and China's responses to Myanmar's development. Moreover, Myanmar has agreed to the ChinaMyanmar Economic Corridor (CMEC) which is a strategically important economic corridor under the umbrella of China's Belt and Road Initiative (BRI). Among various China's BRI projects in Myanmar, every case has a different characteristic, pattern, and situation, in terms of the different fundamental interaction relations among the state, market, and society. It means that China's interest in Myanmar is a complicated and complex situation during Myanmar's new political order. In this sense, the China-Myanmar bilateral relations have the multidimensional factors and it was shaped by the diverse state-holders' interaction. Therefore, this paper will seek the China-Myanmar bilateral relations from the political economy perspective. At last, this paper will argue that the changing relations among state-market-society in Myanmar will play a crucial role in China-Myanmar bilateral relations by using the two-level game theory.
\end{abstract}

\begin{abstract}
Abstrak: Setelah transisi politik Myanmar pada tahun 2011, strategi keterlibatan Tiongkok terhadap Myanmar telah memimpin perubahan dari hubungan negarake-negara menjadi hubungan yang berlapis-lapis. Pada saat yang sama, kebijakan luar negeri Myanmar juga menantang kepentingan ekonomi dan politik Beijing di Myanmar dalam hal penangguhan Bendungan Myit-Sone oleh pemerintah reformasi pertama Myanmar. Kemudian, pemerintah Aung San Suu Kyi melihat lebih dekat dengan RRC dalam kerangka kerja Belt and Road Initiative. Dalam hal ini, mungkin menarik untuk menemukan kebijakan Myanmar tentang keterlibatan Cina dan tanggapan Cina terhadap pembangunan Myanmar. Selain itu, Myanmar telah menyetujui Koridor Ekonomi China-Myanmar (CMEC) yang merupakan koridor ekonomi penting secara strategis di bawah payung China's Belt and Road Initiative (BRI). Di antara berbagai proyek BRI China di Myanmar, setiap kasus memiliki karakteristik, pola, dan situasi yang berbeda, dalam hal hubungan interaksi mendasar yang berbeda antara negara, pasar dan masyarakat. Ini berarti bahwa minat Tiongkok terhadap Myanmar adalah situasi yang rumit dan kompleks selama tatanan politik baru Myanmar. Dalam hal ini, hubungan bilateral China-Myanmar memiliki faktor multidimensi dan dibentuk oleh interaksi beragam pemegang saham negara. Oleh karena itu, paper ini akan
\end{abstract}


mencari hubungan bilateral China-Myanmar dari perspektif ekonomi politik. Akhirnya, makalah ini akan berpendapat bahwa perubahan hubungan antara masyarakat-pasar-masyarakat di Myanmar akan memainkan peran penting bagi hubungan bilateral China-Myanmar dengan menggunakan teori permainan dua tingkat.

Article History: Received: 2020-01-23, Revised: 2020-02-25, Accepted: 2020-06-27

\section{INTRODUCTION}

Myanmar government has gone through different stages of development, economically and politically. During the colonial rule, the British used the laissez-faire economic policy by initiating "export-propelled agriculturalization" as the industrial strategy (Kudo, 2002). However, it was happened as the foreign dominated industrial sector and poor-spread effect for nationwide industrial development. At the era of parliamentary democracy from the 1948 to 1962, the government used the moderate economic nationalism in the framework of market mechanism by using raw materials-oriented import substitution industrialization strategy. There was still at the moderate industrial performance and foreign dominated industrial sector.

At 1962, the military government ruled the nation and initiated the command economy, radical nationalism by releasing the "Burmese ways to socialism". All the economic performance was falling as the result. From the 1988 to 2010, another military leader started indirect military rule called SLORC (State Law and Order Restoration Council) and SPDC (State Peace and Development Council) by using the transitional toward market economy. That was using the agriculture-based and export-oriented industrialization strategy, but still at the crony capitalism. Before 2011, Military government in Myanmar tried to boost the country's economic growth rate because the dictators hoped to get the public legitimacy for their regime by providing the economic prosperity.

The 2011 unexpected political liberalization of Myanmar led by military leaders carried on the new paradigm of not only Myanmar's Domestic politics but also Myanmar's Foreign Relations. Especially, the China-Myanmar bilateral relations have transformed into the multiplayers involving game and more complicated situations. Although the new semi-civilian government led by ex-military leader so called Thein Sein was trying to expand Myanmar's diplomatic space in the international level instead of depending upon the People's Republic of China (PRC)'s supports, but the Rohingya Crisis brought back Myanmar to move close enough with China again because of the China's helps as the diplomatic coverage at the United Nations Security Council (UNSC) and the economic assistance in terms of the Western \& European countries' economic sanctions.

At the same time, the second elected government led by the paramount leader, Aung San Suu Kyi also had the various major challenges under the topics of state-building and nationbuilding in the country, the problems such as ongoing peace process with Ethnic Armed Organizations (EAOs) and Internally Displaced Persons (IDP) Resettlement, the Economic Development, the Constitutional Reforms, the Diplomatic Crisis and Refugee Repatriation in terms of Human Right Violations in Rohingya Crisis, and the Civil-Military Relations, etc. In this sense, the role of China had also increased in Myanmar's political and economic arena because of the two factors.

For the first one, the active and powerful Ethnic Armed Organizations (EAOs) against the Burmese the military are running along the China-Myanmar border areas for the reason of illegal armed trading, and financial survivals in terms of trading the natural resources in the illegal market of the border. As the second one, the main the border economic trading zone and the main logistic route of the China-Myanmar Economic Corridor (CMEC) are in the area of armed conflicts among the Ethnic Armed Organizations (EAOs) and the Defense Service (called Tatmadaw). Therefore, China's role is getting more and more increased in the ways of formal and informal political sphere of Myanmar. 
People Republic of China (PRC) government is always expressed that the country is maintaining the special relations of "Phauk Phaw" between the two countries and the five principles of peaceful coexistence joint declaration that was signed by the two countries at 1954 (Myoe, 2011). But it could be chaotic condition among the scholars for the reason of China's claiming on its border stability and whether the China has the good intention for Myanmar's peace process or not because it seems like that China is playing with fire and water on each hand. It means that China's informal supporting for Myanmar's EAOs challenges Nay Pyi Taw's major interests in terms of security, economic and political affairs.

Generally, the China-Myanmar official diplomatic relations stared on June 8, 1950. And then, the two countries signed the treaty of friendship and mutual non-aggression and jointly released the five principles of the peaceful co-existence on June 29, 1954. Along the history of China-Myanmar relations, China has always supported on the military junta for the economic and political survivals. During the 1988-2010, China supported the economic assistances such as cheap loan, trade, investment, energy deals, military weapons and diplomatic coverage. And then, it supposed that the nearly $60 \%$ of Myanmar's military weapons imported from the China and $42 \%$ of country's foreign direct investment are from China (Malik, 2017).

During the military rule, China engaged with the military leaders for the energy survivals, and geo-strategic reasons. The Shee (1997) pointed out that Myanmar is geographically located at the southwest of China and is strategically important as a land-ridge for the People's Liberation Army Navy (PLAN) in the long-term reasons of becoming the world-class blue-water navy status. The two-ocean policy that was composed the reason to dominate the India Ocean and the Pacific Ocean, is also very important for China's future. And then, the China want to avoid the Malacca dilemma for the energy supply from the Middle Eastern regions by connecting through the gas pipe line from the Kyauk Phyu, Rakine State (Myanmar) to the Kunming, Yunnan Province (China) that is the land-locked province located in Southwest China.

In spite of Myanmar had already signed the agreement for cooperation of ChinaMyanmar Economic Corridor (CMEC) under the umbrella of China's Belt and Road Initiative (BRI), the project implementation process are still facing some problems such as public concerns on Debt Trap, Environmental issues, and local ownership, etc. On the other hand, it had already showed that the Myanmar's one-sided suspension during Thein Sein's presidency on Myit-Sone Dam project also hugely impacted on the China-Myanmar bilateral relations. Therefore, it appears like that Myanmar government is trying to keep balance between the public and China in terms of economic development and foreign relations. Literally speaking, it seems like that Myanmar Government is trying to keep the position between the two relationships among the state-society relations and bilateral relations with China.

On the other hand, People's Republic of China (PRC) has released the ambitious plans of the "Silk Road Economic Belt" and the "21 st Century Maritime Silk Road," called the "OBOR" and the "Belt-and-Road Initiative" on October 2013. And then, China's National Development and Reform Commission, Ministry of Foreign Affairs and Ministry of Commerce delivered the "Vision and Actions on Jointly Building Silk Road Economic Belt and 21 ${ }^{\text {st }}$ Century Maritime Silk Road" (OBOR Vision and Actions) on March 28, 2015.

According to this, it assumed that the Belt and Road Initiative (BRI) will deliver the positive significance, and regional economic cooperation with the other countries in the global level. Although China's reasons on the OBOR are delivering the positive impacts for the global economy, most of the critiques on that plans are still appear and controversial. Therefore, it is widely recognized that the BRI will shaped the new paradigm of geo-political situations around the world.

Although the State to State relations among the China and Myanmar seems the good and warm relationship because of the mutual-benefits in the two countries, the notion of Myanmar's public opinion on the Chinese's investment projects and the figure of China are not good enough to continue the suspended Chinese investment projects in previous Government, such as Myit Sone Dam, and etc. Therefore, China engaged with the multilayered engagement strategy that was composed of engaging with the diverse state-holders in Myanmar instead of using the Stateto-State relation in Myanmar. It was assumed that there are three main objects for China by means of using the multi-layered engagement, to generate the local supports for China's 
economic and geo-strategic interests in Myanmar, to promote the Chinese model of governance and economic development, and to advance the broader interests that include generating supports for the Communist Party of China (CPC) and its territorial claims in the South-China Sea (Kyee, 2018).

In this sense, it could be dilemma for Myanmar Government's Development Dreams and China's Belt and Road Initiative in Myanmar. Therefore, this paper argues that the changing relations among the State-Market-Society in Myanmar will play as the key role for ChinaMyanmar bilateral relations. In this paper, the main argument was based on the two-level game theory of international relations in terms of domestic issues.

\section{China Belt and Road Initiative in Myanmar}

Some analysts supposed that the OBOR initiative aims to counter against the United States' rebalancing Asia policy that was the President Obama's East Asia strategy to maintain the China's rising in Asia and Trans-Pacific Partnership (TPP) (Soong \& Nguyen, 2018). China planned the Asia Infrastructure Investment Bank (AIIB) for the reasons of making the contribution to global economic governance on December 25. 2015. According to the AIIB's official releases, Myanmar became one of the founding members in AIIB on December 25, 2015 and Myanmar received US\$264.5 million as the total subscription (AIIB, 2015).

The proposed the China-Myanmar Economic Corridor (CMEC) which is the key part of China's ambitious Belt and Road Initiative will start in China's Yunnan Province through the Myanmar's main economic cities, such as Mandalay, Yangon, and end at the Kyaukphyu Special Economic Zones (SEZ) in Rakhine State, Myanmar. In that plan, the proposed 24 projects in total were built with the estimated amount of US\$ 2 billion for the initial stage (Lwin, 2019).

Under the umbrella of OBOR, there are six key BRI projects in Myanmar. Three of them are also composed in the CMEC projects, so called the Kayukphyu Deep Sea Port, New Yangon Development Project, and Three Border Economic Zones in Kachin State and Shan State. In that sense, Kyaukphyu Deep Sea Port project was signed as the framework agreement between Myanmar and China on November 2018. This deep seaport will offer the chance for China to access to the Bay of Bengal and it will be for the reason of fixing the "Malacca dilemma" in energy security by throwing the gas pipeline from the Kyaukphyu to Kunming in Yunnan province. Before signing the framework, the public in Myanmar protested that project for several times.

Therefore, the NLD government negotiated again with the China's State-Owned Enterprises (SOEs), called China International Trust Investment Corporation (CITIC) to reduce the size of the project and the total amount of investment from the US\$ 7.5 billion to 1.3 billion (Chau \& Thant, 2018). Although the government announced that the project will create the job opportunities the estimated amount of 100,000 for the local people, some analysts concerns about the problems of debt trap, environment and health problems, and maritime security issues. It seems that the public's involvement on the executive policy making in Myanmar proof the state-society relations and the links with the market demands of Myanmar.

Another proposed project of CMEC is the New Yangon Development Project, which has been signed among the New Yangon Development Company (represent the Myanmar's Government) and China Communications Construction Company (CCCC). But, the role of New Yangon Development Company is also the controversial among the public in Myanmar. It will cost the estimated amount of US\$ 1.5 billion for the various projects such as the new town, the industrial parks, and urban development projects. But some people criticized that it is unnecessary project and raised the concern about the debt trap, the CCCC's negative image of allegation of fraud, corruption, and environmental damage on previous projects (Prasso, 2018). But the government claimed that this project will be benefits for the country because of the Private-Public-Partnership (PPP) type between the Myanmar's Government and China's CCCC. Therefore, it is still the controversial one, especially for the long-term years to get the financial Internal Rate of Return (IRR) of investment among the public in Myanmar.

Myanmar has agreed the sites for the three economic zones in the Kachin State and Shan State along the China-Myanmar border areas on July 10, 2018 (Lwin, 2018). One of them is called the "Kanpiketi Border Economic Zone" which is situated in the Kachin State's Special 
Region 1 that was under the control of the New Democratic Army-Kachin Militia. Another two are "Chin Shwe Haw border economic zone" which is in the area of Shan State's Lauk kai township that was under the control of Kokang Self-Administered Zone and "Muse border economic zone" in Shan State's Muse Township. All the economic zones are in the area of ethnic controlled region and very close with the conflicted area among the Ethnic Armed Organizations (EAOs) and Myanmar's Military Forces. Therefore, some analysts highlight that China desires a peaceful Myanmar especially in border areas to realize its Belt and Road dreams and this will likely encourage China to push for a peace settlement in Myanmar (Kyee, 2018). But Myanmar Government expect to boast their slowing economy by constructing the trade centers, processing plants, small \& medium industrial facilities, trade logistics center, and quality packing center in that three border economic zones.

The Muse-Mandalay Railway project was signed with China in October 2018 for the first stage studying the railway line during one-year period. It is also a part of BRI project in Myanmar to build a parallel expressway and railway line from Ruili (across the border from Muse in China's Yunnan Province) to Kyaukphyu, Rakhine State (Lwin, 2019). The project will pass through some armed conflicted areas in Shan State and the road will be 268 miles long. In that project, it will be the high-speed electric trains and some related buildings, such as freight stations and passenger stations along the route. But, the public concerns about the increasing the armed conflict in that area. Even though, China is increasingly pushing pressure on Ethnic Armed Organizations (EAOs), none of whom are signatories to the Nationwide Ceasefire Agreement (NCA) in Kachin State and Shan State of Myanmar to sign the NCA for the reasons of stability in China-Myanmar border area and the proposed projects area. Therefore, people in Myanmar are much concerned about China's willingness on Myanmar's short-term ceasefire, rather than long-term peace.

China showed the desire to continue the suspended Myitsone Hydropower project in Myanmar during the trip of Chinese Ambassador in Myanmar on December 28 and 29, 2018. Although some Chinese scholar highlighted that southwest China has a large and enough electricity surplus now and claimed that Yunnan does not need to import electricity from Myanmar (Chenyang and Shaojun, 2018), it has revealed that Myitsone Dam project is necessary for BRI projects. But, the people in Myanmar are against the project because of some reasons, the proposed the Myitsone Dam project is located at the confluence of Myanmar's lifeline's the Irrawaddy River, the area of Dam site has a variety of biodiversity to main the ecology of Irrawaddy River, and the potential disruption of water flow downstream on the cities, and villages along the River.

The Kyaukphyu-Kunming Railway was the primary plan of the Belt and Road Initiative for the reasons of logistic linking and commodity distribution from the Kyaukphyu in Rakhine State to Kunming in China's Yunnan Province. It was to run 810 kilometer and estimated cost of US\$ 20 billion. But, the public in Myanmar also concerned about the potential debt trap and armed conflict in that area. Therefore, the former president Thein Sein suspended the project and the project expired in 2014. But China proposed another Railway project from Mandalay to Muse as a part of China-Myanmar Economic Corridor during the National League for Democracy (NLD)'s Government era.

The role of Myanmar in China's Belt and Road Initiative reflected in the facts which two out of six main economic corridors, the Bangladesh-China-India-Myanmar (BCIM) Economic Corridor and the China-Indochina Peninsula Economic Corridor across through Myanmar (Kyee, 2018). The China's CMEC also has the mutual impacts for Myanmar's ongoing peace process because of the Ethnic Armed Organizations (EAOs) based in along the China-Myanmar border area that were not singed the Nationwide Ceasefire Agreement (NCA) with the military (Myanmar's Statutory Armed Forces).

On the one hand, China pushes forward the EAOs to sign the NCA for the reason of stability in the border area and CMEC project area to insure the mutual benefits between China and Myanmar's government. On the other hand, China need to balance their power between the Myanmar government and the Ethnic Armed Organizations (EAOs) for the reason of maintaining the long-term role of China in Myanmar's domestic power and the security of China's investment projects in Ethnic areas, such as Kyaukphyu Deep Sea-Port, Special 
Economic Zone in Rakhine State and Myitsone Dam project, and Border Economic Zones in Kachin State. Therefore, it assumed that China's policy toward Myanmar is the two-handed policy (one hand has the positive and one hand has the negative), literally said "fire in one hand and water in another hand" for the Myanmar Government. And then, another imminent point why Myanmar's Government needs the China is for the reasons of the diplomatic coverage in the international level because of the Rohingya Crisis that was happened in the Rakhine State.

\section{RESEARCH METHOD \\ Two-Level Game Theory and Myanmar's Responses on BRI Projects}

The relationship between the economic development and international relations is a kind of debated issue among the academicians and practitioners. Different school of International Relations tried to approach for seeking this relationship thorough the area of the international system. Some of the scholars like Okano-Heijmans (2011) also characterized the linkage among the area of International Relations, Economics, International Political Economy, and Diplomatic Studies. But, Bayne \& Woolcock (2011) described the main difference among them, like that the discipline of IPE focus on structural factors, the relative power of states of the structures of influence within national economies, rather than on process.

Furthermore, Strange (1994) also supported this argument by providing the structural power concept of the IPE in the international system. Gilpin and Gilpin (2001) also defined the IPE as the reciprocal and dynamic interaction in international relations of the pursuit of wealth and the pursuit of power. The International Political Economy's studying approach looks more broader view and it could be more suitable to explain the international system, economic order and multi-players games in the international system. Therefore, lack of the explanation for assessing the relationship between the two factors, Economic Development and International Relations, encourage to the studies of the new term, called the "Economic Diplomacy".

In this sense, the academic papers, books and article widely used the term of "Economic Diplomacy" to link between the Economic Development and International Relations and for describing these two relationships. It has also different definitions and interpretation among the scholars. But, Bayne \& Woolcock (2011) defined the Economic Diplomacy as the conduct of relations between states and other entities by standing in world politics by officials' agents and by peaceful means. The study on the Economic Diplomacy is composed of the actors, such as State and Non-State Actors, issues, such as the International and Domestic, Instruments and the impact of Market. In the development of Economic Diplomacy, it could be two types of theories, societal theories, and state-centric theories (Bayne \& Woolcock, 2011).

According to this framework, the societal theory focuses on the interaction of different interest groups in the domestic area and access the outcome of this interaction. And then, the state-centric theory more emphasized the institutional structures and intergovernmental actions. The societal theory from this framework also believes that the Government's Policy is the outcome of interaction among the interest groups in the domestic affairs. But there is no clear literature for seeking the outcome of interaction among the interest groups. In this sense, it could be interesting to categorize this literature gap from the political economic conceptual framework.

Therefore, this paper identifies the actors (or) interest groups through the institutional level, such as State, Market and Society. It means that the interaction among the State, Market and Society will shape the policy outcome of the government. It could be more comprehensive, and it is a kind of political economic approach to seek the outcome of interaction among the different interest groups in the domestic sphere. For exploring this gap, the explanation of twolevel of game theory could be suitable method to explain the interaction between the economic development and international relations. In fact, the two-level game explains the interaction between the international and domestic factors and describe the negotiation process at the core of analysis.

Basically, Putnam (1988) initially used the term of "Two-Level games" and introduced the theory for explanation on the interaction between the domestic and international affairs. In the previous literature, Da Conceição-Heldt \& Mello (2017) categorized some of the key debates concerning the levels of analysis in two-level game theory, (1) domestic political institution, (2) 
interaction between the domestic and international affair, (3) actors, (4) actors' interest and preferences, (5) the relationship between the comparative politics and international relations. And then, the two scholars stressed that the foreign policy can't be understood without understanding the country's domestic level of analysis.

In the two-level game theory, there are two types of level, called the level (1)international level, and the level (2)- domestic level. The basic concept is that the deal of international level should be acceptable for domestic level. The level (1) is a kind of negotiation phase and the level (2) is a kind of ratification phase. In this sense, the common negotiator among the level (1) and level (2) could be the government. The government interacts in both levels with the peer negotiator from different countries, and the domestic interest groups. Most of the previous literature agreed that the level (2) interaction can determine the level (1) agreement. Therefore, the government should be considered their level (1) agreement to be the acceptable one in the level (2). Literally, it means that the level (2) has stronger influenceable power than level (1). But it is difficult to suppose that how to interact among the different interest groups in the domestic level. It is also one of literature gap for this theory. But it could be possible that the political economy's institutional analysis through the state, market, and society would be clear solution for that problem.

In this regard, most of the scholars paid attention on the agenda (called the win-set) of the negotiation at the level (1). If the level (2) gives the larger win-set to the government, the government may have the smooth negotiation with the peer negotiators from the different countries at the level (1). Putnam (1988) mentioned the three factors that shapes the win-set, called the preferences and possible coalition, political institutions at the domestic level, and chief negotiators' bargaining strategies at the international level. But there is no clear rule (or) way of thinking how to get the larger win-set in the domestic level. In the domestic level, the biggest challenges for the government are the question of how to approach to the different stakeholders in the various interest groups. Therefore, Bayne \& Woolcock (2011) mentioned that the government is trying to reconcile the three types of tension in their book, called the New Economic Diplomacy. The first one could be the tension between politics and economics, the second one would be the tension of between the international and domestic pressure, and the third one might be the tension between government and other actors, such as private business and civil society (Bayne \& Woolcock, 2011).

Sometimes, the three tensions happens together at the same time in some countries. But there is no academic contribution to explain that kind of conditions in the previous literature. It could be possible to explain this condition from the political economic perspective using this research's conceptual framework. It means that the tension might be the dealings between the interaction among the state, market and society in the domestic level and the foreign relations (or) foreign investor in the country at the international level. In the practical sense, it is similar with the research question of this research. Therefore, Okano-Heijmans (2011) expressed the importance of economic diplomacy while describing the relationship between the economic development and international relations. And then, it could be noted that the economic diplomacy is a kind of foreign policy practice and strategy based on the economic and political interests (Okano-Heijmans, 2011).

The NLD government's economic policy reform (especially the macroeconomic stability and dealing with the foreign direct investment) seems the pragmatic realism and it tries to approach the state-led development model. On the other hand, it could be doubt whether the development policy based on the two growth centers (Yangon and Mandalay) will cover the whole society in the country or not? It would be sensible to heed the consequence of wealth distribution problems for the whole society. As one of the characteristics for the notion of the State, the equity in the distribution of benefits and burden would also matter among the unequal states or regions in Myanmar, as the form of political problem while acquiring the democratic federal union. It seems like getting the sense of injustice and inequality for the public in ethnic areas.

Moreover, other pressure points for Myanmar's government to the shifting of state-led development model might be the question of how to develop active government and technocratic bureaucracy. In this sense, the institutional weakness in terms of assistance with 
capital accumulation and technology acquisition could play the critical role for managing the China's investment projects in Myanmar. If not, the sense of managing the China's BRI projects significantly would tend to under the condition of China's manipulation. Furthermore, the lack of technocratic bureaucracy also matters for addressing the different forms of rent-seeking, and financing problems (such as dealing for the Internal Rate of Return). Therefore, the government seriously needs to initiative the institutional capability not only for managing the China's BRI, but also for implementing the state-led development model.

The situation of Market's imperfect competition also impacts on growing the crony capitalism and increasing the informal business sectors in Myanmar. Market's stability, efficiency, and growth factors are hugely driven by those conditions. Therefore, it would significantly impact on the driving forces for distribution of wealth in the society. According to various literatures, it has already showed that the Foreign Direct Investment in the imperfect competition has the negative effects on long-term economic development in the country (Schneider \& Frey, 1985).

Myanmar Sustainable Development Plan was released by the Ministry of Planning and Finance under the Government of National League for Democracy (NLD) led by Daw Aung San Suu Kyi for the ambitious national development goals and objectives. According to the MSDP, it is started for the reasons of delivering coherence to policies and filling the institutional necessaries for genuine, inclusive and transformational growth (Ministry of Planning and Finance, 2018). The MSDP has the three pillars composed of five goals, twenty-eight strategies, and two hundred and thirty-eight action plans. And then, all these plans are firmly aligned with the other global and regional development plans, such as SDGs, Greater Mekong Sub-Region Strategies Framework and the ASEAN Economic Community (AEC). Furthermore, the second goals of pillar number one and the pillar number two are totally related with the economic development.

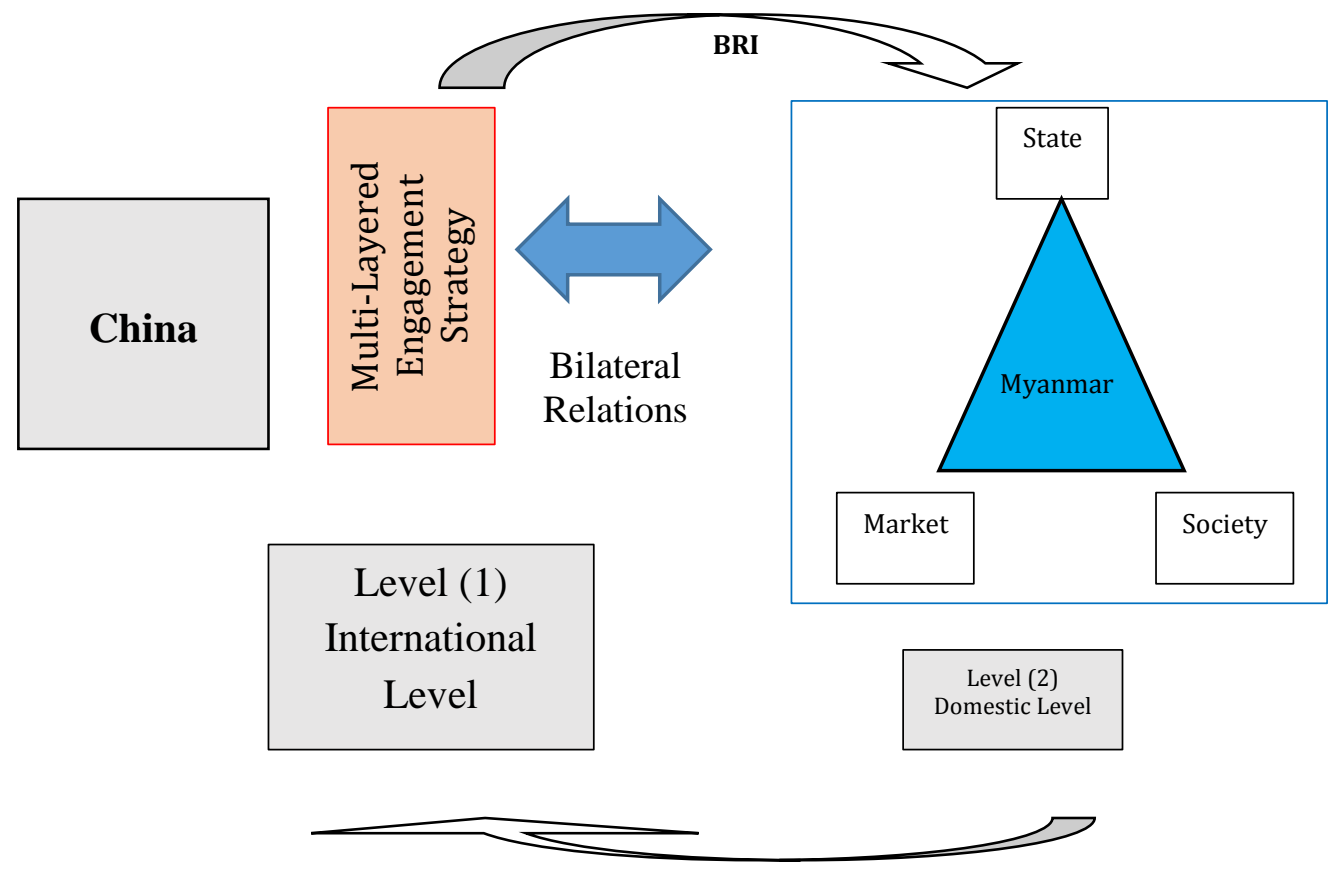

Figure.1

Conceptual Framework of China-Myanmar Relations under the BRI Framework Source: Author (2020)

In figure. 1 show the first pillar, called the Peace and Stability, there are two goals that were composed for the reasons of Peace, National Reconciliation, Security and Good Governance as the first one and Economic Stability, Strengthened Macro-economic Management as the second one. For the first one, it aims the union-wide peace, socio economic development, rule of law, good governance and institutional performance, and social inclusion (Ministry of Planning and Finance, 2018). For the second one, it targets the stable exchange rate for effectively 
managing the exchange rate and balance of payments, monetary stability for reducing inflation and maintaining monetary stability, transparent tax system for increasing financial resources through a fair and transparent tax system, strong public financial management for strengthening public financial management to support the stability and the efficient allocations of public resources, and competitive state-owned enterprises for enhancing the efficiency and competitiveness of state-owned enterprises (Ministry of Planning and Finance, 2018).

In the second pillar, "Prosperity and Partnership", it focused on the seven areas, such as the rural development and agriculture for creating diverse and productive economy with rural development and agriculture as the foundation, job creation for supporting job creation in industry and service, especially through the development of SMEs, enabling the investment for improving enabling environment for investment, trade sector reform for further reforming the trade sector and strengthening regional and international co-operations and linkages, financial access for increasing access to financial service and strengthening the financial system, infrastructure for building the infrastructure for growth and economic diversification, and creativity \& innovation for supporting creativity and innovation to develop a modern economy (Ministry of Planning and Finance, 2018). For the last pillar, "People and Planet," it expressed the five factors, access to education, strong healthcare system, social safety net, food safety, and protection of the rights for all.

Myanmar Government tried to increase the economic cooperation with other East Asia countries for the infrastructure supplies, such as Japan, South-Korea, and Taiwan. According to some sources, it arrived the US\$ 1.48 billion of Japanese investment in 2017 (Lwin, 2018). But China was always the biggest investor since 1988. China's investment in Myanmar will be around the US\$20.24 billion from 1988 to 2018 (Lwin, 2019). It is not new between the China and Japan for competing on Myanmar's Economic battleground. But Myanmar people more prefer the Japanese investment rather than Chinese investment because of ethical issues, technological supports, and job opportunities.

Moreover, the forty percent of the foreign debt in Myanmar owned to the China. Therefore, some analysts concern about the debt trap like such countries, Sri Lanka, Pakistan and Malaysia (now suspend some Chinese projects). Although the bilateral relations in State level between the China and Myanmar is warm and keep the good condition, it is difficult to suppose that the state-society relation in Myanmar and people to people relations between the two countries are in the good condition because of the unequal and non-justice economic deals. In the condition of demanding the market for the economic development of Myanmar, Myanmar government is facing the resistance of public involvement in executive policy making process. On the other hand, Myanmar government looks hooping as the "Free Rider" in China's Belt and Road Initiative (BRI). But Myanmar's institutional weakness and various interest groups are also challenging toward to the "Fail Rider" in the BRI case. In this sense, it could be appropriate way to pay attention the relationship among the economic development and international relations in terms of domestic issues and foreign relations.

\section{RESULT AND DICUSSION \\ Theoretical Discussion: The Relationship among the State, Market and Society}

Generally, the interaction between the state and market is the debated issue for every nation state since long years ago. This is the biggest question ever for political economist. Different school of thoughts had different opinion and approach on the role of State in Market. Even in Neo-Classical School, the two schools called the Austrian Economics (Keynesian Economics) and Cambridge Economics also have the different ontological and epistemological assumptions of the interaction between the state and market. In modern era, this question belongs with the country's economic policy making. In fact, it is a place to meet the two institutions of politics and economy.

Basically, the politics is the studies of power relations and the economics is the studies of Human's decision making under the condition of scarcity. In this sense, the political economy is the studies of State and Market interaction and it seeks the questions of resource sharing, equality, effectiveness, etc. Therefore, the critical question is that in which condition the state's involvement is effective to the market's efficiency and how to perform that functions. In other 
words, Ferenčak, Crnković \& Rudan (2014) mentioned that the market (invisible hand) does need, more or less, the help of the state (visible hand). But, later the studies of the role of the government (or) state became part of the main-stream economy called the Public Finance (in the 19th century) and Public Economy (1960s).

In this sense, the two main questions of positive approach and normative approach are different with each other. The normative approach tries to answer the question, "How government policies should be designed to attain certain objectives?" and the positive approach tries to seek the question, "How do government policies affect the economy?" (Bozio \& Disney, 2011). In the neoliberal mode of Capitalism, the main reasons why the role of government is increasing in the market are because of the Market Failure, and Redistribution.

Moreover, the scholar like Auerbach, Chetty, Feldstein \& Saez (2013) pointed out the factors of Market Failure in the Handbook of Public Economy (2013), called the Externalities, Imperfect Competition, Imperfect (or) Asymmetric Information, and Individual Failure. And then, the government should intervene in the market because of the unequal distribution as the second reason. The area of the interaction between the State and Market derived the original political economy of David Ricardo and John Stuart Mill. Hindriks \& Myles (2013) also mentioned that the public economic has now returned to its roots as the new political economy.

However, the studies of State-Market interaction seem like the studies of economic efficiency, distribution and economic policy. In some sense, it attempts to know about who the government makes the decision, what decision it should make and their impacts. Therefore, it could be assumed that it is necessary to seek the motives of the decision makers in the rules of the game (or) institutional limits and the political \& economic incentives for the policy makers and other interest groups.

Furthermore, it is also essential to link between the public economy and the practical economic development model for exploring the questions, such as "What kind of State's intervention in the Market benefits to the Economic Development?" Therefore, most of the public economist paid the attention the geographic area of economic development model. As the example, the East Asia Economic Development Model (or) Asia Miracle is different with the Western and European Development Model. In the East Asia Countries' Economic history, the State played the key role and took the highest role for implementing the economic policy.

Basically, the State needs to guarantee the values such as individual freedom, the social order and the equity in the distribution of benefits and burden. And the Market also promote its functions like the efficiency, stability and growth. Sometimes, the interaction between the State and Market is not clear to distinguish that which one is State's force, and which one is Market's efficiency. Especially, the developing countries which has the weak institution in terms of private and public have showed that the State performed as the Market's function when the Market is performing some State's functions in developed countries.

The book defined the State-Society relations as the interaction between the state institutions and societal groups to negotiate how public authority is exercised and how it can influence by people (Dagnino, 2016). The scholar, Migdal (1988) pointed out that the state represented the rules of justice. Therefore, the citizen always demands the sense of justice from the State. But, the moment in the condition of sense of injustice, the relations between the State and Society is getting worse and worse. And then, the state-market-society relations differs with the changes of regime types in the country. The state-market-society relations in the authoritarian regime will be the top-down structure and in the democratic regime is the parallel structure. Therefore, it could be also academic contribution by investigating the state-society relations in Myanmar and the questions as "Why does the public resist the China's BRI projects although Myanmar need the economic assistance for sustainable development?" This research will touch this question also.

Moreover, Zhiping (1999) mentioned that what is the significance in differentiating "society" and "market" while, as an independent element, "society" is interjected between market and state. In some sense, it was assumed that markets involve spontaneous action among equal and private actors, the stat involves hierarchical and public actions through institutions of human construction. For the society, most of the literature refers as the civil society. In the western notion of civil society, it was recognized that there are two leading school 
of thoughts, led by Locke, and led by Montesquieu (Zhiping, 1999). And then, Jessen (2017) also mentioned the civil society as the third sphere or sector outside the state and market.

In the Locke's school, the civil society as the entity completely independent of politics, a view that was supported by its incorporation of theories of the market and the economic system. And then, Montesquieu believe that government and society can't be fully separated, certain structural requirements within the interior organization of the state are necessary to protect freedom and impose restraint on political power. And then, the state-society also does matters in this case. Therefore, some literature defined the state-society relations like that the interaction between state institutions and societal groups to negotiate how public authority is exercised and how it can be influenced by the people (Haider, 2010).

Welton (2001) and Taylor (2004) also highlighted that the strong and independent civil society and public sphere is in the liberal-democratic imaginary constitutive of the strength of liberal democracy and the independence of civil society from state and market both factually and normatively constitutive of modern, democratic societies. And then, Jessen (2017) tried to develop a cultural political economy approach by arguing the separation between state, market and civil society that is the constitutive feature of the liberal-democratic, capitalist imaginary which serves to delineate and depoliticize civil society as something outside state and market, which can be appropriated, administered and governed for appropriate aim, such as welfare services. And then, it was recognized that the separation among the state, market and society (civil society) is a distinct and constitutive feature of modern, western political modernity, and liberal, representative democracy (Neoclecous, 1996).

\section{Discussion: State-Market-Society Interaction of Myanmar toward the China's BRI}

Basically, the state and market interaction in transition period of developing countries is complicated and debated issue ever. Especially, the country like Myanmar has more complicated political economy structures. Since 1989, Myanmar's crony capitalism boomed in terms of increasing the illegal industries of informal money-making sectors. This political economy structure of Myanmar shaped the current political economy of reform structures. Despite the State's intention toward the Chinese BRI projects are good, the Market and the Society's intention are not good intention. Therefore, it could be important to assess the interaction among the State-Market-Society toward the China's BRI projects in Myanmar.
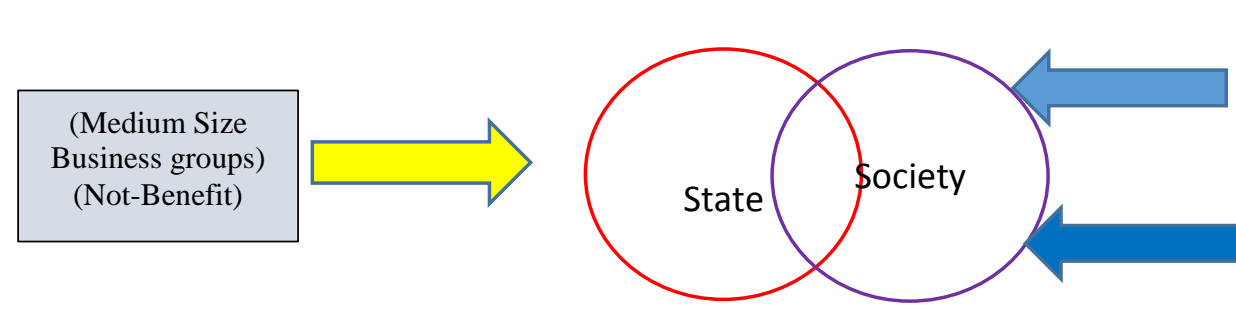

Figure.2

Analysis of State-Market Interaction toward the Chinese BRI projects Source: Author (2020)

In figure. 2 shows this case, the state supposes that the Chinese BRI projects will support Myanmar's Economic Development and especially the socio-economic development of the local people. It means that the State hopes to promote individual freedom, social order and the equity to the public by initiating the economic prosperity in the market. Most of the actors from the State institution responded as the positive intention of this project. On the other hand, the Market's normative values are efficiency, stability, and growth in the literature. In this case, the different levels of actors in the market sector have diverse impacts on this project. But it has a lack of efficiency and stability. It supposes that the market can't distribute among the diverse level of society.

Generally, most of the scholars have already agreed that Myanmar's state-society relations has changed from the bottom-up relations to parallel position of relations. The 
society's role has highly increased since the political liberalization at 2011 and the society's voices impacts the executive policy making of the State institutions. As the commitment of the State institution, the government needs to equity in the distribution of benefits and burden among the social classes of the whole society. In the condition of Market can't perform fully its Market function, the State need to adjust the Market's functions. In this sense, State performs the Market's function in some ways.

On the other hand, the Society always demands the values, such as the security, freedom, welfare, order and justice from the State. If the state can't deliver the values and functions to the Society, the clashes between the State and Society happens. Therefore, the State-Society interaction also plays the key role for the Development. Generally, the topics in the area of StateSociety interaction covers the questions of mutual rights and obligation of state and society, and how to use the public resources for the Development.

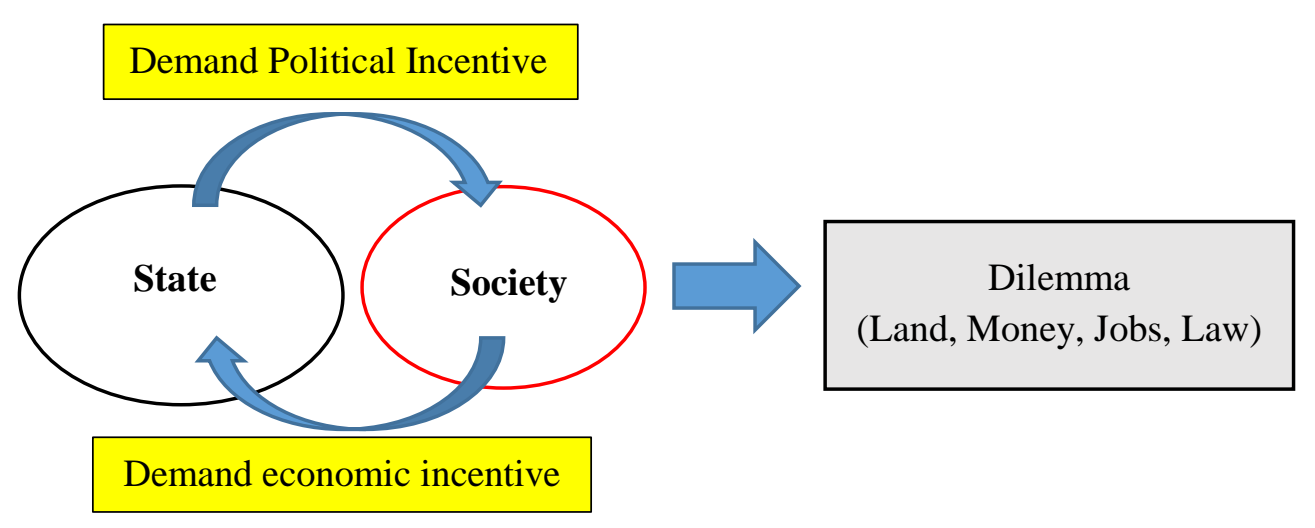

Figure.3

Analysis of State-Society Interaction toward the Chinese BRI Projects Source: Author (2020)

Based on figure. 3 the Society demands the economic incentives from the Chinese BRI project. But the State can't perform to fulfill the Society's needs and wants. At the same time, the State demands the political incentive from the Society for their political benefits. In this sense, the society's demands such as the money, jobs also directly challenge the State's law and land monopolizing. Therefore, this paper assumes that it could be possible as the dilemma in terms of the Land, Money, Jobs and Law for interacting between the State and the Society toward the Chinese BRI projects in Myanmar.

Despite the neo-classical model of development is trying to be market society for capitalist economic system, sometimes it could not be possible to be the market society in some countries. The long year of isolated society which has the command socialist economic system is not easy to be the western model of market society during a short period of time. In Myanmar, the political economy of transition is more complicated and complex in terms of bureaucratic corruption and rent seeking, etc.

Moreover, Myanmar's Market-Society also has the problems among the different social classes of society. Along the Military rule, the tycoon businessmen who are close with the Military leaders got many business opportunities and created the wealth and power for their own benefits. Therefore, the public's injustice sense and anger toward the tycoon businessmen were getting increased day by day. Therefore, the society don't have too much good perception on the Market sector because all the business opportunities were dominated by the crony businessmen and the market is always monopolistic competition. But, the clash between the Market and Society is not strong like the clashes between the State and Society. The Market demand the resources from the society and the Society demands the prosperity. 


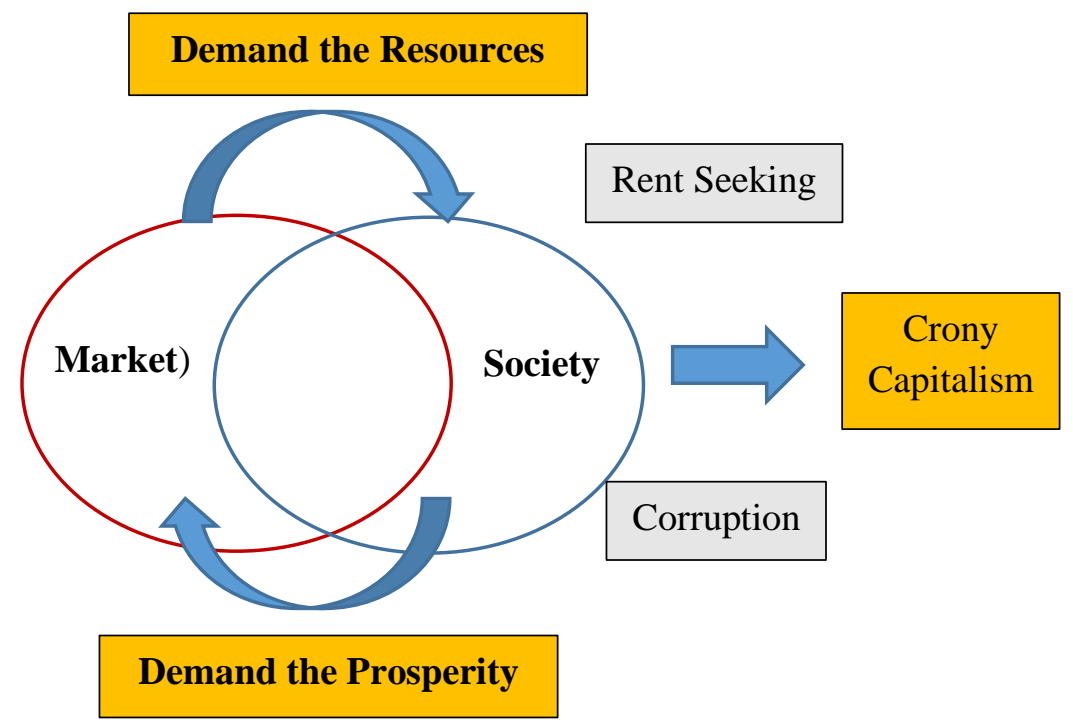

Figure.4

Analysis of Market-Society Interaction toward the Chinese BRI Projects Source: Author (2020)

From figure.4 shows the two-level game perspective, the domestic interaction at the level (2) will impact on the international relations at the level (1). It is sure that the different BRI projects have the diverse interaction and different pattern of dominated approaches in Myanmar. Moreover, the Myanmar government should be concerned that every Foreign Direct Investment (FDI) could not benefit to the Economic Development of the host country. Therefore, the Myanmar Government should pay attention and prepare the six key factors, (1) Macroeconomic Stability, (2) Political Stability, (3) Institutional Capacity and Enable Infrastructures, (4) Legal Foundations in terms of protection for ownership and Intellectual Property, (5) National Development Plan which composed of the Poverty Reduction Strategy, (6) National Education Policy which will implement the academic and vocational education.

It could be possible to accept that the success of implementing the China-Myanmar Economic Corridor (CMEC) under the umbrella of BRI will depend on the State-Market-Society interaction of Myanmar. This interaction wills portrait not only the Myanmar's current political economic ecology but also the future China-Myanmar bilateral relations. The factors such as the State-Market Relations, the State-Society Relations, and the Market-Society Relations of Myanmar will make the judgement for the success of China-Myanmar Economic Corridor (CMEC) and Myanmar's Economic Development potentials.

Generally, it is sure that the China-Myanmar Economic Corridor (CMEC) projects will not successfully implemented without getting the Myanmar public's positive intention. But Myanmar's society has hugely negative perception on Chinese investment projects in Myanmar in terms of Environmental Issues, Land Problems, Not Equal Benefit to the local community. It has showed that in the case of Letpadaung Copper Mine, Myit-Sone Dam Project, Kyauk-Phyu Special Economic Zone and Deep Seaport Project, even the New Yangon Development Project. The growing sense of society's negative perception on Chinese investment projects in Myanmar is not a good sign for China-Myanmar Economic Corridor. On the other hand, it can drop down the Myanmar's State-Society Relations into the negative position. Basically, the Society demands the values such as Security, Freedom, Welfare, Stability, and Justice from the State. The StateSociety Relations is getting worse and worse in the condition when the State can't offer these values to the society.

Sometimes, the State delivers these values through the Market to the Society when the State's condition is not ready to deliver these values to the Society, especially for the Welfare. But the pattern of Chinese investment projects is different with the Western census. Moreover, 
Chinese investment projects are based on the two governments' deals. Therefore, it excludes the local business groups to involve in the huge market, excepts the small numbers of Tycoon Businessmen (or) Crony Businessmen. It could be assumed that it might be the results of the Myanmar Government's tender system and the State's ideology on the Market. In fact, it is not the appropriate way to establish the enable the political economic environment. Therefore, the Myanmar Government should create the political economic climate which encourages the Market to be growth, efficiency and stability for delivering the Society's demands.

The China-Myanmar Economic Corridor (CEMC) could make Myanmar to lead more complicated situations because most of the projects under the CMEC are at the Ethnic areas. The existing problems in the State-Market Relations and State-Society Relations became from the traditional way to more complicated political problems. Furthermore, it stimulates Myanmar's ongoing the Federal debates. Especially, Ethnic community's negative perception is rising on the reason why they don't get any befits from the CMEC projects and it is because of lacking the selfdetermination and equal opportunities. It really leads to the Armed Conflicts and Political Violence in Myanmar.

Beside these problems, Myanmar may lead to the type of Cron-Capitalism because the State tried to establish the monopolistic market dominated by the few tycoon businessmen instead of establishing the Free Market which has the right to involve by everyone. In fact, the non-functioning market will not deliver its resource distribution mechanism very well. And it may create another unnecessary problem such as Rent Seeking and Corruption in the Society. Moreover, rising the huge inequality in the society is the result of these problems. When the very few percentages of the society are getting richer than before through their financial capital, the most percentage of the society in the lowest level are not ready to face the skyrocketed living prices. Therefore, Myanmar Government should create the condition which can help to harmonize the different level of classes in the society by initiating the efficient Market System and creating job opportunities.

\section{CONCLUSION}

The China-Myanmar bilateral relation is also the controversial and debated issue in the regional content. The bilateral relations between the China and Myanmar under the umbrella of OBOR will depend on the performance of how Myanmar's Government manage the relations between the State and Society within the country to balance the economic and political longterm benefits, and the China's willingness on Myanmar's Development. Therefore, it is important that not to lead the Zero-Sum game situations. And then, China need to appearance that the economic cooperation between the two countries will enhance the mutual benefits and the Chinese investment projects are also ensuing the international rules and regulations on the border trade, environment impacts, and labor right, etc.

As the policy suggestions, the Myanmar's Government should be developed as the integrated policy mechanism for the co-operation with the foreign direct investment projects, especially with the OBOR projects in Myanmar. And then, the government in Myanmar should release the transparent project deals with the China to the public. It really inspires to be the good state-society relations in Myanmar. Moreover, another important thing is the law enforcement on the foreign direct investment projects to be responsible business on the society and environmental protection mechanisms, and the protection for the business projects intellectually and physically also plays the key role for implementing the decent relations between the state and market.

Furthermore, this research suggests some of the political reform process, such as Political Decentralization and Financial Decentralization. It could really help to the Government for implementing State's Development Projects. And the Myanmar Government need to reform the Bureaucratic System as the Technocratic Meritocracy System. It could be essential part for implementing the Development Projects. It means that the Government need to reform the political process and economic institutions also at the same time.

For the China perspective, the PRC's Government should regulate its State-Owned Enterprises (SOEs) and another Chinese business investment projects to be the figure of responsible investment by adopting the Standard Operating Procedures (SOPs) in the global level. And then, another related problem proposed in other countries, such as illegal blue-collar 
worker migrants who are coming together with the investment projects, also makes the inferior impression for the Chinese investment projects around the world. Therefore, the PRC Government should give the attention about that kind of problems by instigating the rule and regulations. It really encourages being good relations between the proposed country and China for the three-level engagement, State to State, Market to Market and Society to Society.

It should be noted that the State-Market-Society relations in Myanmar will shape the new paradigm of China-Myanmar relations for the future. And then, it assumed that the political economy of Myanmar's Development should be multilateral and holistic approach, rather than dependence only on China. Therefore, it is the time for the policy makers and various stateholders in Myanmar to reshape the figure of Myanmar in the international community by enhancing the economic prosperity and political stability. On the other hand, it will also be the chance for China to redesign about the negative images of OBOR (such as the debt trap in Sri Lanka, Pakistan, etc.) in the international chapter by bringing the mutual benefits in the case of China-Myanmar Economic Corridor (CMEC).

\section{REFERENCE}

AIIB. (2015,). Members and Prospective Members of the Bank. Retrieved from Asia Infrastructure Investment Bank (AIIB): https://www.aiib.org/en/aboutaiib/governance/membersofbank/index.html

Auerbach, A. J., Chetty, R., Feldstein, M., \& Saez, E. (Eds.). (2013). Handbook of public economics (Vol. 5). Newnes.

Bayne, N., \& Woolcock, S. (Eds.). (2011). The new economic diplomacy: decision-making and negotiation in international economic relations. Ashgate Publishing, Ltd.

Bayne, N., \& Woolcock, S. (Eds.). (2011). The new economic diplomacy: decision-making and negotiation in international economic relations. Ashgate Publishing, Ltd.

Bozio, A., \& Disney, R. (2011). Public sector pays and pensions. The IFS Green Budget, 163-191.

Chenyang, L., \& Shaojun, S. (2018). “China's OBOR Initiative and Myanmar's Political Economy." The Chinese Economy, 51(4), 318-332.

da Conceição-Heldt, E., \& Mello, P. A. (2017). "Two-level games in foreign policy analysis." Oxford Research Encyclopedia of Politics, 1-33

Dagnino, E. (2016). "State-society relations and the dilemmas of the new Developmentalist State", IDS Bulletin Transforming Development Knowledge, 47 (2A), 157-191

Ferenčak, I., Crnković, B., \& Rudan, S. (2014). "State and market." Ekonomski vjesnik: Review of Contemporary Entrepreneurship, Business, and Economic Issues, 27(1), 113-126.

Gilpin, R., \& Gilpin, J. M. (2001). Global political economy: Understanding the international economic order. Princeton University Press.

Haider, H. (2010). State-society relations and citizenship in situations of conflict and fragility. GSDRC, University of Birmingham.

Hindriks, J., \& Myles, G. D. (2013). Intermediate public economics. MIT press.

Jessen, M. H. (2017). Civil Society in the Shadow of the Neoliberal State: On the Depoliticization of Civil Society, 1992-present. www.research.cbs.dk.

Kudo, T. (2002). Industrial development in Myanmar: Prospects and challenges. Institute of Developing Economies Japan External Trade Organization.

Kyee, K. K. (2018). “China's Multi-Layered Engagement Strategy and Myanmar's Reality: The Best Fit for Beijing's Preferences." ISP Myanmar Working Paper Series, 1(1), 1 -99.

Kyee, K. K. (2018). "Finding Peace along the China-Myanmar Economic Corridor: Between Short-term Interests and Long-lasting Peace." ISP-Myanmar working paper series, 1(2), 1-37.

Lwin, N. (2018, August 10). China Beating Japan in War for Economic Influence in Myanmar. Retrieved from The Irrawaddy (English Edition): https://www.irrawaddy.com/news/burma/chinabeating-japan-wareconomicinfluence-myanmar.html

Lwin, N. (2018, July 13). Govt Approves Sites For 3 New Economic Zones Along China Border. Retrieved from The Irrawaddy: 
https://www.irrawaddy.com/business/govtapprovessites-3- new-economic-zonesalong-china border.html

Lwin, N. (2019, January 24). China's Six Belt and Road Projects in Myanmar to watch in 2019. Retrieved from The Irrawaddy (English Edition): https://www.irrawaddy.com/specials/chinassix-belt-road-projects-myanmar-watch2019.html

Lwin, N. (2019, January 25). Info-graphic: 30 Years of Chinese Investment in Myanmar. Retrieved from The Irrawaddy (English https://www.irrawaddy.com/specials/infographic-30-yearschinese investmentmyanmar.html

Malik, J. M. (2018). “Myanmar's role in China's Maritime Silk Road Initiative.” Journal of Contemporary China, 27(111), 362-378.

Migdal, J. S. (1988). Strong societies and weak states: state-society relations and state capabilities in the Third World. Princeton University Press.

Ministry of Planning and Finance, M. (2018). Myanmar Sustainable Development Plan. Nay Pyi Taw: Republic of the Union of Myanmar.

Neocleous, M. (1996). Administering civil society: Towards a theory of state power. Springer.

Okano-Heijmans, M. (2011). "Conceptualizing economic diplomacy: The crossroads of international relations, economics, IPE and diplomatic studies." The Hague journal of diplomacy, 6(1-2), 7-36.

Okano-Heijmans, M. (2011). "Conceptualizing economic diplomacy: The crossroads of international relations, economics, IPE and diplomatic studies." The Hague journal of diplomacy, 6(1-2), 7-36.

Persson, T., Roland, G., \& Tabellini, G. (2000). "Comparative politics and public finance." Journal of political Economy, 108(6), 1121-1161.

Putnam, R. D. (1988). "Diplomacy and domestic politics: the logic of two-level games." International organization, 42(3), 427-460.

Schneider, F., \& Frey, B. S. (1985). "Economic and political determinants of foreign direct investment." World development, 13(2), 161-175.

Shee, P. K. (1997). "The political economy of China-Myanmar relations: Strategic and economic dimensions." Southeast Asia, 19(1), 33-53.

Strange, S. (1994). Wake up, Krasner! The world has changed. Taylor \& Francis

Welton, M. (2001). "Civil society and the public sphere: Habermas's recent learning theory." Studies in the Education of Adults, 33(1), 20-34.

Zhiping, L. (1999). "Market, Society, and the State. Chinese Economy," 32(4), 41-45. 